\title{
Revealed Comparative Advantage of Bangladeshi Leather Industry with Selected Asian Economies
}

\author{
Saiful Islam, Parag Jafar Siddique \\ (School of Business and Economics, United International University, Dhaka, Bangladesh)
}

\begin{abstract}
This study analyses the comparative advantage and the pattern of trade flows of Bangladeshi leather industry with comparison to other selected Asian countries- Pakistan, China and India.This research adopted well recognized measure of Revealed Comparative Advantage (RCA)-Balassa's Index. Bangladesh categorizes its overall leather export into two categories, i.e., I. Raw hides \& skins, and II. Leather \& leather products. An in-depth RCA has been conducted for these two categories followed by an analysis of overall industry. The analysis shows that Bangladesh has a comparatively high RCA in overall leather exportswith other selected countries from 2004 to 2013 which is driven by a very high RCA in raw hides \& skins exports. This indicates that Bangladesh has significant potentiality for specialization in leather export especially raw hides \& skins. Therefore, entrepreneurs and policy makers should specialize in raw hides and skins productions and exports to generate more export revenues for the country.
\end{abstract}

Keywords: Balassa's Index, Bangladesh, Leather Industry, Leather\& leather products, Raw hides \& skins, Revealed Comparative Advantage

\section{Introduction}

Decline in barriers to the free flow of goods, services, and capital and advancement in technological change, especially in communication, information processing and transportation technologies, have made the world closer than ever [1] [2]. In the wave of globalization, countries are exporting goods and services in which they are more efficient, to a barrier free world market. Such efficiency rationalizes the specialization of a country in the production of those goods in which they have a comparative advantage. Among the Asian economies, China and India have proved immense potentiality to be the leader in world trade based on their specialized production. Bangladesh, another potential Asian economy, also showed their comparative advantage in labor intensive production by exporting Ready Made Garments (RMG).

Success in RMG sector indicates country's specialization in labor incentive products. Leather industry is another sector, where Bangladesh might posses the potentiality to be specialized. Availability of indigenous raw material (hides and skins), facilitate the leather processing in this country for a long heritage of over seven decades. The industry was established in early 1940 in the then East Pakistan. After independence, like present Pakistan, Bangladesh has also posses the prospect for specialization in its emerging leather industry. According to Bangladesh Board of Investment (BOI), it produces around 2-3\% of the world's leather from a ready supply of raw materials and the leather industry is ideally suited to Bangladesh with its abundance of labor and natural resources at internationally competitive rates.

Comparative advantage is the term used to describe the notion that, a country should specialize in the production of those goods that they can produce in lower opportunity cost than others. In other words, a country can produce its products with different level of cost per unit of production. They should specialize in the production of those goods that they can produce with lower relative cost than other countries. And then with international trade, country can obtain other goods at a lower price (opportunity cost), in exchange for the good in which it has a comparative advantage [3]. While, Ricardian theory stated comparative advantage due to technological dissimilarities across nations, $\mathrm{H}-\mathrm{O}$ theory considers cost dissimilarities arising due to differences in factor prices across nations. , assuming constant technology.

There are some other theoretical procedure to "reveal" a country's comparative advantage using a variety of techniques. Among these, focusing estimation of comparative advantage of any country rather than focusing on determining its sources, Balassa [4] provided a measure to identify a country's revealed comparative advantage named Balassa Index. This study is aim to 'reveal' the comparative advantage of leather industry of Bangladesh, if any, in comparison to other selected Asian countries- Pakistan, China and India. This study, focus on export data of leather industry of Bangladesh- both in Raw hides and skins and Leather and leather goods with selected countries to answer the question of whether Bangladesh should devote its more scarce resources to leather industry or not.

The paper is organized as follows. In the next section recent literature on the issue is discussed. In section 3, some presents facts about the leather industry of Bangladesh are presented. Some comparison with other selected economies and detail picture of the export of leather industry of Bangladesh is mentioned in this 
section following by section 4 , the methodology to estimate RCA. In section 5 the results are analyzed followed by conclusions and some recommendation in section 6 .

\section{Literature Review}

Measuring the potentiality and implementing further policy reforms to an industry, number of studies has been focused on the concept of revealed comparative advantage. Majority of those studies relied on the data of export shares of these industries, compare to overall export of the nation. Balassa [4] initially has shown the relative trade performances of individual countries in particular commodities for major industrial countries by introducing the concept of 'revealed' comparative advantage. Later, Balassa [5] has undertaken a comparative study for industrial countries for the period 1953 to 1971 to address the change of comparative advantage. In accordance to this study, Balassa and Noland [6] also confirmed the diversification and specialization through technological advancement in industrialized countries.

Several studies have also been conducted in selected industry on the basis of assuming regional similarities and advantages over other regions of the world. When Spair [7] focused on trade shares among European countries, Yeats [8] analyzed MERCOSUR countries. In addition to discriminatory trade barriers found in these studies, Richardson and Zhang [9], when compared the trade performance of USA with other regional trading partners, found differences due to geographical immediacy of trading partners and per capita income over time and across sectors. Moreover, Bender and Li [10] also observed related changes in export pattern among different Asian and Latin American regions.

However, previous studies in specific country within region are not rare. Karaalp [11] has analyzed the effects of the customs union on the comparative advantage of the Turkish manufacturing industry. Moreover, using Balassa's [4] measure of relative export performance by country and industry, Utkulu and Seymen[12] analyzed the sector specific competitiveness and the pattern of trade flows from Turkey to European Union. Batra and Khan [13] have investigated the same, considering structural change across sectors and product using Indian and Chinese data. In addition to these, Yue [14] has found that, China has changed its export pattern to coincide with its comparative advantage.

A handsome number of empirical studies are prominent in explaining the different sectors and industries of Pakistan, using Balassa's [4] measure of relative comparative advantage. Hanif and Jafri [15] analyzed the textile sector of Pakistan. On the other hand, Akhtar et al. [16] have investigated the performance of footwear industry of Pakistan in comparison with China and India. While Mahmood [17] explores export specialization of Pakistan's non-agriculture production sectors, Akhtar et al. [18] examined competitiveness of selected Pakistani fruits with major global fruit. On the other hand, Shahab and Mahmood [3] have analyzed the trade specialization in the leather products of Pakistan with other selected Asian economies- China, India and Iran. This study ignored another potential Asian economy of leather export- Bangladesh.

In the context of Bangladesh, such studies of exploring revealed comparative advantage are few and dedicated to some specific industry. Karaalp and Yilmaz [19] analyzes the comparative advantage of four countries in the world: Bangladesh, China, Germany and Turkey with respect to the US and the EU-15 textiles and clothing markets by employing Balassa's revealed comparative advantage (RCA) index. They found that the Bangladesh clothing industry has a substantially higher comparative advantage in all three markets compared to the other countries. Bhuyan and Ray [20], Siriwardana and Yang [21], and Rahman et al. [22] also made some empirical studies in evaluating the comparative advantage of Bangladesh at bilateral and regional levels, especially in comparison with SAARC (South Asian Association for Regional Cooperation) countries.

However, none of these studies have focused on leather industry of Bangladesh. As a labor-intensive export sector, leather industry of Bangladesh has a comparatively better potentiality for export performance. It indicates the need for an in-depth analysis of this industry to reveal comparative advantage, if any, compare to other selected countries in Asian region. The above stated empirical studies on revealed comparative advantage provide rationale for using Balassa's [4] measure of relative comparative advantage for leather industry of Bangladesh.

\section{Present Export Scenario of Bangladesh Leather Industry}

As a sub sector of manufacturing, leather industry has a long enriched history of growth in Bangladesh. Because of available indigenous raw material (hides and skins) in the region, in early 1940s leather processing industry was established in the then East Pakistan. During that Pakistan period (1947-1971), it was dominated by non-Bengali migrants from India, who had the knowledge and the know-how of leather processing industry. At that time, leather processing was limited to the production of wet blue leather (semiprocessed tanned leather) and the non-Bengali traders exported a large part of the produce to West Pakistan for further processing and production of leather goods [23]. 
Table 1: Exports Performance of Selected Asian Economies in leather Products

\begin{tabular}{|c|c|c|c|c|}
\hline \multicolumn{5}{|c|}{ Total Leather Exports of selected countries (USD thousands) } \\
\hline Years & Bangladesh & Pakistan & China & India \\
\hline 2004 & 229,744 & 782,541 & $11,659,910$ & $1,696,944$ \\
\hline 2005 & 243,509 & 999,377 & $12,986,112$ & $1,837,089$ \\
\hline 2006 & 255,261 & 998,088 & $14,163,205$ & $1,945,452$ \\
\hline 2007 & 300,845 & $1,083,503$ & $15,504,757$ & $2,133,166$ \\
\hline 2008 & 270,492 & $1,149,966$ & $17,388,358$ & $2,467,690$ \\
\hline 2009 & 191,476 & 848,250 & $15,357,217$ & $1,979,553$ \\
\hline 2010 & 278,856 & $1,034,494$ & $21,257,313$ & $2,236,828$ \\
\hline 2011 & 356,467 & $1,149,226$ & $27,345,116$ & $3,038,528$ \\
\hline 2012 & 377,285 & $1,131,210$ & $28,689,030$ & $3,110,121$ \\
\hline 2013 & 368,858 & $1,273,236$ & $31,146,565$ & $3,862,247$ \\
\hline \multicolumn{5}{|c|}{ Source: ITC, COMTRADE data } \\
\hline
\end{tabular}

After the independence, Bangladesh could ensure a little success to reform the industry under the public sector. New development and technological change was not originated until 1990 when a ban on export of wet blue leather was imposed worldwide. Sequential government initiatives in 1971, 1981 and finally 1990 got the momentum, only when modern leather tanning units for the production of crust and finished leather was set up followed by new investment in leather goods industry, particularly leather footwear. However, till this twenty first century, leather industry inhabits only a self-effacing position in Bangladesh economy way below its true potential [23]. Moreover, government acknowledging the fact, now a day's focusing more to change the scenario and already announced leather industry as one of its thrust sector for new investment.

According to Bangladesh Board of Investment (BOI), it produces around 2-3\% of the world's leather from a ready supply of raw materials and the leather industry is ideally suited to Bangladesh with its abundance of labor and natural resources at internationally competitive rates. The total exports of leather industry of Bangladesh are classified into two main categories, one is Raw hides \& skins and another one is Leather and leather products. As raw materials are more abundant in the country, Bangladesh maintaining its potentiality in the export of is raw skins and Leather to the world, which support the figure provided by BOI. After 1990, Bangladesh is also focusing more to improve its status for exporting more Leather and leather productsincluding footwear and leather garments, but such initiatives did not get enough success till today.

Table 2: Growth in the Value of total leather Exports

\begin{tabular}{|c|c|c|c|c|}
\hline \multicolumn{3}{|c|}{ Growth of exports in value (\%) } \\
\hline Years & Bangladesh & Pakistan & China & India \\
\hline 2005 & 5.99 & 27.71 & 11.37 & 8.26 \\
\hline 2006 & 4.83 & -0.13 & 9.06 & 5.90 \\
\hline 2007 & 17.86 & 8.56 & 9.47 & 9.65 \\
\hline 2008 & -10.09 & 6.13 & 12.15 & 15.68 \\
\hline 2009 & -29.21 & -26.24 & -11.68 & -19.78 \\
\hline 2010 & 45.63 & 21.96 & 38.42 & 13.00 \\
\hline 2011 & 27.83 & 11.09 & 28.64 & 35.84 \\
\hline 2012 & 5.84 & -1.57 & 4.91 & 2.36 \\
\hline 2013 & -2.23 & 12.56 & 8.57 & 24.18 \\
\hline
\end{tabular}

Some export status of Bangladesh leather industry, in comparison with other selected Asian countries, is presented in the Table 1 and Table 2. Table 1 represents exports performance of Bangladesh, Pakistan, China and India in leather products from 2004 to 2013 time period. During this decade, total Bangladeshi leather export has been increased more than $60 \%$. Other Asian countries are also showing similar trend, e.g., Pakistan $62 \%$, China $167 \%$ and India $127 \%$. However, these growth patterns are not same for all selected countries, over the period. Growth pattern in the value of total leather exports are presented in the Table 2. For Bangladesh, the growth rate is very unstable with sharp ups and down, which is quite similar with Pakistan in nature. Both countries experienced positive and negative growth over the selected period whereas selected all four countries experienced a sharp negative growth in 2009 and again recovered it. Bangladesh recovered in following year from common decline in 2009 with highest growth rate in 2010. However, when other three countries- Pakistan, China, and India have a positive growth in very recent year in 2013, Bangladesh experienced a negative rate. The inconsistent surges of total leather industry growth for selected countries are also plotted in Fig. 1. 


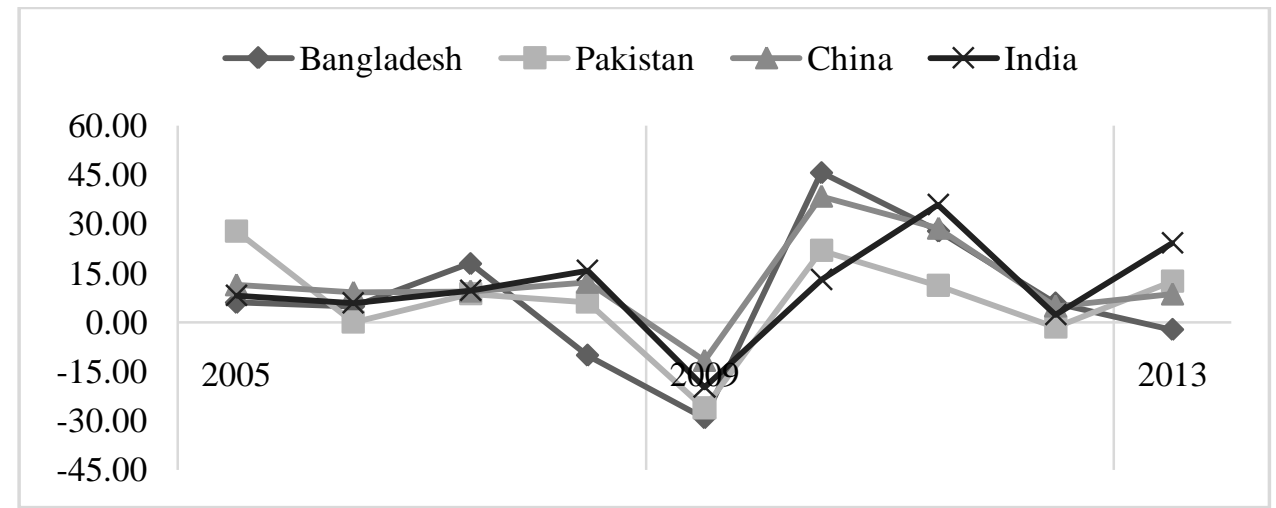

Fig. 1: Growth Pattern in Leather export for selected Asian countries

Moreover, in Table 3, the classified growth patterns of Bangladesh leather industry are presented. When, growth of total leather industry shows inconsistent negative and positive growth rate, in two categoriesLeather and leather product category showed only positive growth from 2005 to 2013. A very interesting fact is that, the export of total leather industry of Bangladesh is largely dominated by the export of raw hides \& skins. As a result, growth rates and patterns for both total leather export and raw hides \& skins export are almost similar between 2005 and 2013 (Fig. 2).

Table 3: Export Growth of overall Leather industry of Bangladesh

\begin{tabular}{|c|c|c|c|}
\hline Year & $\begin{array}{c}\text { Growth of Total } \\
\text { Leather Export }\end{array}$ & $\begin{array}{c}\text { Growth of Raw } \\
\text { Hides and Skins }\end{array}$ & $\begin{array}{c}\text { Growth of } \\
\text { Leather Products }\end{array}$ \\
\hline 2005 & 5.99 & 5.47 & 29.96 \\
\hline 2006 & 4.83 & 4.64 & 11.87 \\
\hline 2007 & 17.86 & 17.23 & 39.90 \\
\hline 2008 & -10.09 & -13.01 & 75.77 \\
\hline 2009 & -29.21 & -32.48 & 18.33 \\
\hline 2010 & 45.63 & 46.49 & 38.53 \\
\hline 2011 & 27.83 & 27.09 & 34.33 \\
\hline 2012 & 5.84 & -1.25 & 64.74 \\
\hline 2013 & -2.23 & -11.06 & 41.74 \\
\hline
\end{tabular}

In Table 4 percentage of total leather export to country's total export and to world's total export are presented for selected four countries over the period of 2004-2013. While Bangladesh exports below then 1 percent of world's total leather export, it accounts 2 to 3 percent of country's total export earnings in 2002-2013. On the other hand, in Pakistan, leather export accounts 5-7 percents on average of its total export earnings, which higher than selected any countries, but it serve only 1-2 percents of total world's leather export. China serve highest $25-30 \%$ on average of world's total leather export, which account only 1-2\% of its total export earnings. On the other hand, like China in India, leather export accounts only $1-2 \%$ of its total export on average, but it serves world's total leather export lower than China- $2-4 \%$ on average.

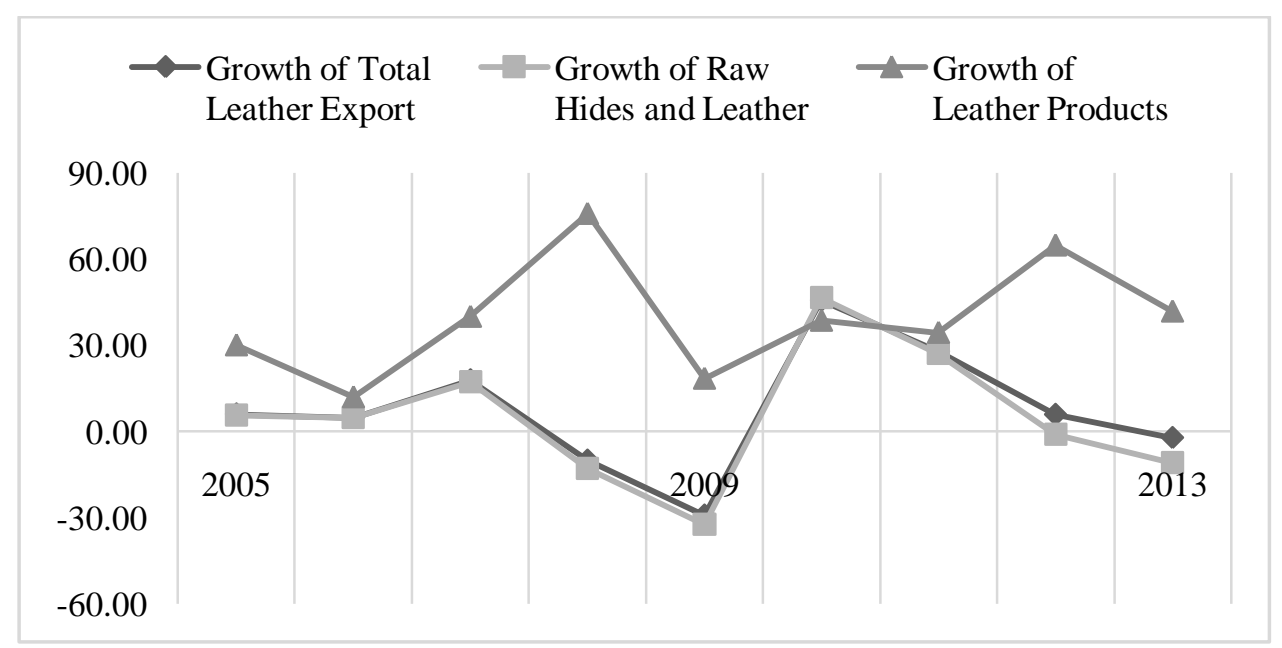

Fig. 2: Growth of leather Exports of Bangladesh 
Beside these export potentiality, however, Bangladesh face couple of challenges and problem in leather sector, which tentatively poses the threat for expansion of leather export. Lack of an integrated comprehensive policy with proper inputs by all the stakeholders, inexperienced entrepreneurs and poor infrastructural development forces most of the exporters to engage in irregular production and exports. No industrial support for linkages factories and lack of institutional facilities for training and development, industry has any available trained human resource as well as managerial positions. Other than these, government poor coordination, lack of focus, and absence of thrust for development, the export growth of Bangladesh leather industry could not match its true potentials till now.

Table 4: Leather Exports Shares in Total Exports \& world's total leather Exports

\begin{tabular}{|c|c|c|c|c|c|c|c|c|}
\hline \multirow[b]{2}{*}{ Years } & \multicolumn{2}{|c|}{ Bangladesh } & \multicolumn{2}{|c|}{ Pakistan } & \multicolumn{2}{|c|}{ China } & \multicolumn{2}{|c|}{ India } \\
\hline & $\begin{array}{c}\% \text { of } \\
\text { Total } \\
\text { Export }\end{array}$ & $\begin{array}{c}\% \text { of } \\
\text { World Total } \\
\text { Leather } \\
\text { Export } \\
\end{array}$ & $\begin{array}{c}\% \text { of } \\
\text { Total } \\
\text { Export }\end{array}$ & $\begin{array}{c}\% \text { of } \\
\text { World Total } \\
\text { Leather } \\
\text { Export } \\
\end{array}$ & $\begin{array}{c}\% \text { of } \\
\text { Total } \\
\text { Export }\end{array}$ & $\begin{array}{c}\% \text { of } \\
\text { World Total } \\
\text { Leather } \\
\text { Export } \\
\end{array}$ & $\begin{array}{c}\% \text { of } \\
\text { Total } \\
\text { Export }\end{array}$ & $\begin{array}{c}\% \text { of } \\
\text { World Total } \\
\text { Leather } \\
\text { Export } \\
\end{array}$ \\
\hline 2004 & 2.78 & 0.39 & 5.85 & 1.33 & 1.97 & 19.86 & 2.24 & 2.89 \\
\hline 2005 & 2.61 & 0.39 & 6.23 & 1.61 & 1.70 & 20.91 & 1.83 & 2.96 \\
\hline 2006 & 2.18 & 0.38 & 5.89 & 1.47 & 1.46 & 20.91 & 1.61 & 2.87 \\
\hline 2007 & 2.29 & 0.40 & 6.07 & 1.43 & 1.27 & 20.40 & 1.46 & 2.81 \\
\hline 2008 & 1.59 & 0.34 & 5.67 & 1.46 & 1.22 & 22.06 & 1.36 & 3.13 \\
\hline 2009 & 1.11 & 0.30 & 4.83 & 1.32 & 1.28 & 23.94 & 1.12 & 3.09 \\
\hline 2010 & 1.35 & 0.34 & 4.83 & 1.26 & 1.35 & 25.83 & 1.01 & 2.72 \\
\hline 2011 & 1.32 & 0.36 & 4.53 & 1.17 & 1.44 & 27.78 & 1.01 & 3.09 \\
\hline 2012 & 1.40 & 0.38 & 4.60 & 1.13 & 1.40 & 28.54 & 1.07 & 3.09 \\
\hline 2013 & 1.20 & 0.36 & 5.07 & 1.26 & 1.41 & 30.80 & 1.15 & 3.82 \\
\hline \multicolumn{9}{|c|}{ Source: ITC, COMTRADE data } \\
\hline
\end{tabular}

\section{Methodology}

Revealed comparative advantage (RCA) indices offer a useful way of analyzing a country's comparative advantage, based on demonstrated (i.e. actual) export performance. There are couples of techniques to measure a country's revealed comparative advantage. One is Balassa's [4][5][24][25] RCA index (denoted as RCA) that compares the export share of a given sector in a country with the export share of that sector in the world market. It is concerns to the relative trade performance of individual countries in particular commodities. The factors that contribute to movements in RCA are economic: structural change, improved world demand and trade specialization [13][10][26].

In this study Balassa's RCA index is used, which is a standard approach or methodology to estimate a country's comparative advantage or comparative disadvantage in commodities, industries or sectors [27]. RCA index defines the pattern in comparative advantage by using the trade flows, since this pattern in comparative advantage is revealed by the observed pattern of trade flows, therefore it is called 'revealed comparative advantage [3]. The index for country i commodity $\mathrm{j}$ is calculated as follows:

Where,

$$
\mathrm{RCA}_{\mathrm{ij}}=\frac{\mathrm{X}_{\mathrm{ij}} / \mathrm{X}_{\mathrm{wj}}}{\mathrm{X}_{\mathrm{i}} / \mathrm{X}_{\mathrm{w}}}
$$

$X_{i j}=i$ th country's export of commodity $j$

$\mathrm{X}_{\mathrm{wj}}=$ world exports of commodity $\mathrm{j}$

$X_{i}=$ total exports of country $i$

$\mathrm{X}_{\mathrm{w}}=$ total world exports

Here the numerator is the share of a country's total exports of the selected product in its total exports. The denominator is share of world exports of the same product in total world exports. The index of revealed comparative advantage $\left(\mathrm{RCA}_{\mathrm{ij}}\right)$ has a relatively simple interpretation. It takes a value between 0 and positive infinity. If it takes a value greater than unity, the country has a revealed comparative advantage in that product and a value lower than unity, country has comparative disadvantage in that product. The index might be affected by anything that distorts the trade pattern, e.g., trade barriers.

A country reveals comparative advantages in products for which this indicator is higher than 1 , showing that its exports of those products are more than expected on the basis of its importance in total exports of the world. The advantage of using the comparative advantage index is that it considers the intrinsic advantage of a particular export commodity and is consistent with changes in an economy's relative factor endowment and productivity. However, the disadvantages are that it cannot detect the source of comparative advantage or disadvantage, improvements in factor endowments and pursuit of appropriate trade policies by a country [13][3]. 
Other than the model specifications, major data sources for calculating RCA index are world development indicators (WDI) developed by World Bank and UN COMTRADE for the period of 2004-2013. In this context, data are collected for Harmonized System (HS) code 41 and 42 for selected number of countries. HS code 41 represents Raw hides \& skins, whereas HS code 42 represents Leather and leather products. Some other secondary data has been collected from Bangladesh Board of Investment (BOI), Bangladesh Export Promotion Bureau and Bangladesh Bureau of Statistics to present the present export scenario of Bangladesh.

\section{Reveal Comparative Analysis}

This section of the study is developed to presenting the results of the analysis performed on collected data to determine the pattern of revealed comparative advantage in leather industry for Bangladesh, Pakistan, China and India. An overview of revealed comparative advantage index for the period of 2004 to 2013 has been presented in two proportions. First, overall industry index has been presented and second, an in depth analysis has been configured for sub category of leather industry- Raw hides \& skins and Leather and leather products category.

Table 5: Revealed Comparative Advantage Index of selected countries

\begin{tabular}{|c|c|c|c|c|}
\hline Year & Bangladesh & Pakistan & China & India \\
\hline 2004 & 4.31 & 9.06 & 3.05 & 3.46 \\
\hline 2005 & 4.36 & 10.40 & 2.85 & 3.06 \\
\hline 2006 & 3.86 & 10.43 & 2.59 & 2.84 \\
\hline 2007 & 4.16 & 11.05 & 2.31 & 2.66 \\
\hline 2008 & 3.21 & 11.49 & 2.46 & 2.75 \\
\hline 2009 & 2.14 & 9.33 & 2.47 & 2.16 \\
\hline 2010 & 2.49 & 8.88 & 2.48 & 1.87 \\
\hline 2011 & 2.45 & 8.38 & 2.66 & 1.86 \\
\hline 2012 & 2.52 & 8.28 & 2.52 & 1.93 \\
\hline 2013 & 2.14 & 9.02 & 2.51 & 2.04 \\
\hline
\end{tabular}

Table 5 shows the comparative view of revealed comparative advantage index for overall leather industry of Bangladesh, Pakistan, China and India for period of 2004 to 2013. The results show that, for all the selected Asian countries, revealed comparative advantage index is greater than unity $(\mathrm{RCA}>1)$ which indicates a significant potential growth of these countries in leather industry. Though, all country has comparative advantage in this industry, the pattern is not similar for each country over years. Moreover, results indicate some interesting insights. Bangladesh has a stable comparative advantage in the leather industry but it decreased in recent periods compare to early years of study. A similar pattern and same level of comparative advantage is also found for giant economy- China. India also has comparative advantage but decreasing in nature and lower than both Bangladesh and China.

In the contrary to other countries, Pakistan has a prominent potentiality in leather industry based on its revealed comparative advantage index. Though, Pakistan also experiencing a decreasing comparative advantage, it is much stable over years and substantially much greater than other countries of the study. However, to identify problem areas and to suggest future policy measure for capturing greater potentialities from leather industry for Bangladesh, a single index of overall leather industry might insufficient. To address narrower understanding, in Table 6, a detail revealed comparative advantage index has been presented for sub categories of leather industry. Bangladesh government categorize total export of its leather industry in two group- first, Raw hides \& skins export and second, Leather and leather products.

Table 6: Details Revealed Comparative Advantage Index for Leather Industry for countries

\begin{tabular}{|c|c|c|c|c|c|c|c|c|}
\hline \multirow[b]{2}{*}{ Year } & \multicolumn{2}{|c|}{ Bangladesh } & \multicolumn{2}{|c|}{ Pakistan } & \multicolumn{2}{|c|}{ China } & \multicolumn{2}{|c|}{ India } \\
\hline & $\begin{array}{c}\text { Raw hides } \\
\text { \& skins }\end{array}$ & $\begin{array}{c}\text { Leather and } \\
\text { leather } \\
\text { products }\end{array}$ & $\begin{array}{c}\text { Raw hides } \\
\text { \& skins }\end{array}$ & $\begin{array}{c}\text { Leather and } \\
\text { leather } \\
\text { products }\end{array}$ & $\begin{array}{c}\text { Raw hides } \\
\text { \& skins }\end{array}$ & $\begin{array}{c}\text { Leather and } \\
\text { leather } \\
\text { products }\end{array}$ & $\begin{array}{c}\text { Raw hides } \\
\text { \& skins }\end{array}$ & $\begin{array}{c}\text { Leather and } \\
\text { leather } \\
\text { products }\end{array}$ \\
\hline 2004 & 9.29 & 0.17 & 7.30 & 10.53 & 0.81 & 4.90 & 2.71 & 4.09 \\
\hline 2005 & 9.88 & 0.20 & 7.43 & 12.63 & 0.80 & 4.39 & 2.49 & 3.48 \\
\hline 2006 & 8.74 & 0.19 & 7.73 & 12.47 & 0.75 & 3.97 & 2.46 & 3.13 \\
\hline 2007 & 9.69 & 0.23 & 9.62 & 12.07 & 0.42 & 3.65 & 2.42 & 2.83 \\
\hline 2008 & 8.15 & 0.33 & 10.38 & 12.14 & 0.15 & 3.81 & 2.56 & 2.86 \\
\hline 2009 & 5.87 & 0.34 & 9.14 & 9.42 & 0.12 & 3.60 & 1.89 & 2.30 \\
\hline 2010 & 6.09 & 0.40 & 9.73 & 8.39 & 0.13 & 3.84 & 1.80 & 1.91 \\
\hline 2011 & 6.60 & 0.39 & 10.31 & 7.42 & 0.13 & 3.91 & 1.88 & 1.85 \\
\hline 2012 & 6.61 & 0.62 & 10.54 & 7.22 & 0.12 & 3.64 & 2.10 & 1.86 \\
\hline 2013 & 5.10 & 0.76 & 11.81 & 7.72 & 0.12 & 3.62 & 2.24 & 1.95 \\
\hline
\end{tabular}


Bangladesh has a revealed comparative advantage in the export of raw hides and leather. The index is more than unity and quite stable over years and higher to all other countries except Pakistan. At the same time, Bangladesh has no comparative advantage in the production of Leather and Leather Products category. A similar scenario is also found for China but in opposite direction. China has a positive comparative advantage index for Leather and leather products but no comparative advantage in export of Raw hides \& skins. Both Pakistan and India shows positive scores in comparative advantage measure for both category of leather industry. However, India's index is much lower compare to Pakistan in both categories. Pakistan is the country which has huge potentiality for growth in both categories of leather industry, because it has substantially higher indexes in revealed comparative advantage score compare to its second competing countries.

\section{Conclusions}

In this study we have analyzed the performance of leather industry in Bangladesh and made its comparison with India, Pakistan and China. Balassa's RCA index has been employed to analyze exports of leather industry from year 2004 to 2013. From the results it has been observed that RCA index is greater than unity for overall leather industry of Bangladesh, which means Bangladeshi leather products have significant potentiality in international export. To get clearer picture of this scenario, we further extended our research for raw hides \& skins and Leathers and leather products. For the case of raw hides \& skins, Bangladesh has a higher RCA index except Pakistan, which means Bangladesh can play important role in the export of raw hides \& skins in the international market. On the other hand, RCA index for leather products is less than one. However, a promising trend has been observed, as index has been increased about $60 \%$ in the last decade.

This study has revealed that Bangladesh has a potentiality to invest more and expand in leather industry which substantially because of raw hides \& skins exports. This observation will be helpful for the entrepreneurs and policy makers of the leather industry. If the entrepreneurs and policy makers concentrate more on raw hides $\&$ skins category export, then country can earn more export revenue. Moreover, leather goods sector should also be equally emphasized to keep its present growth and achieve a RCA index greater than unity.

This is a preliminary study on Bangladeshi leather export. Though two major categories of leather industry has been analyzed in this study, more in-depth analysis could be followed by this study, e.g. footwear industry, leather clothing, and other leather items. As Bangladesh has high RCA index and moreover, among the four countries of this study, Bangladesh comes in the second position, which certainly means that leather sector can play a very important role in the economic growth of Bangladesh compared to other selected economies.

\section{References}

[1] Frankel, J. (2000). "Globalization of the Economy". National Bureau of Economic Research, Working Paper No 7858

[2] Hill, C. (2010). "International Business: Competitng in the Global Marketplace", 8th ed, McGraw-Hill/Irwin, p.11.

[3] Shahab, S., \&Mahmood, M. T. (2013). "Comparative Advantage of Leather Industry in Pakistan with Selected Asian Economies", International Journal of Economics and Financial Issues 3(1), 133-139.

[4] Balassa, B. (1965). "Trade Liberalization and 'Revealed' Comparative Advantage", ManchesterSchool of Economic and Social Studies, 33 (May), pp. 90-123.

[5] Balassa, B. (1977). "'Revealed' Comparative Advantage Revisited: An Analysis of Relative Export Shares of the Industrial Countries, 1953-1971”, Manchester School of Economic \& Social Studies, 1977, vol. 45, issue 4, pp. 327-44.

[6] Balassa, B., \& Noland, M. (1989). "Revealed Comparative Advantage in Japan and United States", Journal of International Economic Integration, 4(2), Autumn, 1989, pp. 8-22.

[7] Sapir, A. (1992). "Regional Integration in Europe." Economic Journal 102(415, November):1491-1506.

[8] Yeats, A. J. (1998). "Does Mercosur's Trade Performance Raise Concerns about the Effects of Regional Trade Arrangements?", The World Bank Economic Review, Vol 12(1), pp. 1-28.

[9] Richardson, D.J., \& Zhang, C. (1999). "Revealing Comparative Advantage: Chaotic or Coherent Patterns Across Time and Sector and U.S Trading Partner?", National Bureau of Economic Research, Working Paper 7212.

[10] Bender, S., \& Li, Kui-Wai (2002). "The Changing Trade and Revealed Comparative Advantages of Asian and Latin American Manufacture Exports", Working Papers 843, Economic Growth Center, Yale University.

[11] Karaalp, H. S. (2012). "Effects of the Customs Union on Comparative Advantage of Turkish Manufacturing Industry", International Journal of Contemporary Economics and Administrative Sciences, Vol: 2, Issue: 2, pp. 117- 129

[12] Utkulu, U., \&Seymen, D. (2004). "Revealed Comparative Advantage and Competitiveness: Evidence for Turkey vis-à-vis the EU/15", paper prepared for the European Trade Group 6th Annual Conference, ETSG 2004, Nottingham.

[13] Batra, A., \& Khan, Z. (2005). "Revealed Comparative Advantage: An Analysis for India and China”, Working Paper No 168, Indian Council for Research on International Economic Relations (ICRIER), New Delhi.

[14] Yue, C. (2001). "Comparative Advantage, Exchange Rate and Exports in China", paper prepared for the International Conference on Chinese economy, CERDI, France.

[15] Hanif, M. N., \& Jafri, S.K. (2006). "Financial Development and Textile Sector Competitiveness: A Case Study of Pakistan", South Asia Economic Journal, 9:1, pp. 141-158.

[16] Akhtar, N., Zakir, N., \&Ghani, E. (2008). "Changing Revealed Comparative Advantage: A Case Study of Footwear Industry of Pakistan", The Pakistan Development Review, 47: 4 Part II (Winter 2008), pp. 695-709.

[17] Mahmood A. (2004). "Export Competitiveness and Comparative Advantage of Pakistan's Non agricultural Production Sectors: Trends and Analysis", The Pakistan Development Review, 43: 4 Part II (Winter 2004) pp. 541-561

[18] Akhtar, W., Sharif, M., \& Shah, H. (2009). "Competitiveness of Pakistani Fruits in the World Market". The Lahore Journal of Economics, vol. 14(2), pp. 125-133. 
[19] Karaalp, H. S., \&Yilmaz, N. D. (2013). "Comparative Advantage of Textiles and Clothing: Evidence for Bangladesh, China, Germany and Turkey", FIBRES \& TEXTILES in Eastern Europe 2013; 21, 1(97): 14-17.

[20] Bhuyan, A. R. and Ray, S. (2006). "Feasibility study on bilateral FTA within SAARC region", Report 2, ACE, Spain.

[21] Siriwardana, M. and Yang, J. (2007). "Effects of Proposed Free Trade Agreement between India and Bangladesh", South Asia Economic Journal, 8(1), pp. 21-38.

[22] Rahman. M., Towfiqul. I. K., Ashiqun. N. and Tapas. K. P. (2011). "Bangladesh's Export Opportunities in the Indian Market: Addressing Barriers and Strategies for Future", South Asia Economic Journal, 12(1), pp. 117-141.

[23] Ahmed, N., \&Bakht, Z. (2010). "Leather Footwear Industry in Dhaka: A Case Study", Bangladesh Institute of Development Studies, June 2010.

[24] Balassa, B. (1979). "The Changing Pattern of Comparative Advantage in Manufactured Goods," Review of Economics and Statistics, 61 (May), pp. 259-266.

[25] Balassa, B. (1986). "Comparative Advantage in Manufactured Goods: A Reappraisal", The Review of Economics and Statistics, Vol. 68, No. 2, pp. 315-319.

[26] Riaz, K., \& Jansen, H. G. P. (2012). "Spatial patterns of revealed comparative of Pakistan's agricultural exports", Pakistan Economic and Social Review, 50(2), 97-120.

[27] Ahmad, N. and Kalim, R. (2013). "Changing Revealed Comparative Advantage of Textile and Clothing Sector of Pakistan: Pre and Post Quota Analysis", Pakistan Journal of Commerce and Social Sciences, Vol. 7 (3), 520-544. 